\title{
WOMAN AND TECHNOLOGY: A STUDY ON GENDER PORTRAYAL OF A FEMALE CYBORG IN GHOST IN THE SHELL (2017) MOVIE \\ Pujo Sakti Nur Cahyo ${ }^{1} \&$ Riyan Evrilia Suryaningtyas ${ }^{2}$ \\ ${ }^{I}$ English Department, Universitas Airlangga Surabaya, East Java, Indonesia \\ ${ }^{2}$ English Department, Universitas Airlangga Surabaya, East Java, Indonesia \\ Corresponding Author: Pujo Sakti Nur Cahyo, E-mail: pujosakti-n-c@ fib.unair.ac.id
}

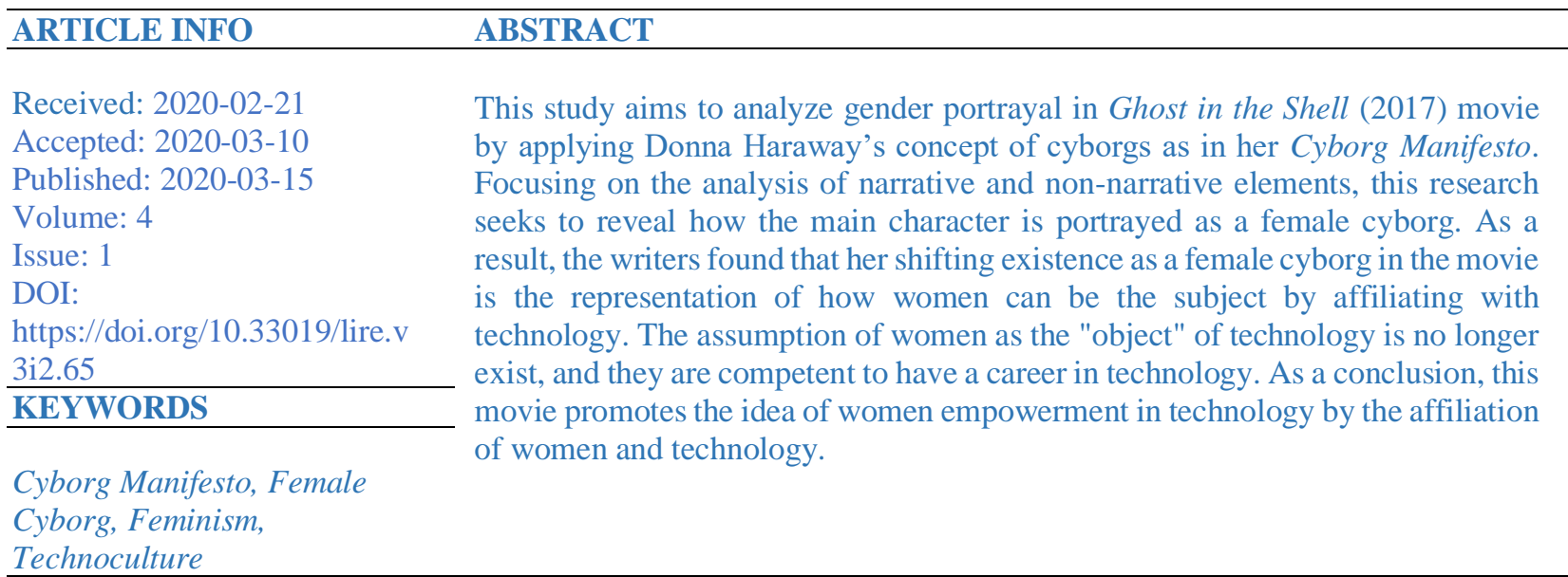

\section{INTRODUCTION}

As a product of civilization, the technology exists with its initial purpose to help humans "engage with the world" more conveniently (Cooper, 2010, p. 4). The role of technology in human life is more and more intensified as technoculture emerged in the $21^{\text {st }}$ century. According to Debra Shaw, technoculture is the relationship between technology and culture and the expression of that relationship in patterns of social life, economic structures, politics, art, literature, and popular culture (Cooper, 2010). That being so, technology has become an inseparable aspect of modern life to such an extent that it is very influential to the meaning and the meaning-making of cultural practices and artifacts; while on the other hand, its development is highly influenced by culture as well and therefore reflects its values and meanings.

For example, the human-like androids that are designed to have female features represent the place of women as the object of men mastery such as Erica, Jia Jia, and Sophia. Their body is designed to have the ideal body of women and a beautiful face which emphasizes that female robots are the media to fulfill the male gaze. Erica has been called the most beautiful robot in the world. She also has a doll-like physique and style. Jia Jia was inspired by an old story about a fairy (Love, 2018). While, Sophia's appearance was designed with the "classic beauty" of a British actress named Audrey Hepburn (BBC, 2017). It emphasizes that technology is designed to fulfill men's desire. They use it to reproduce the existing hierarchies where men dominate the production and women play the role as the object of male's desire (Johnston, 2001). The portrayal of humanoid robots as female emphasizes that women as the product of male domination in a patriarchal society. Patriarchy believes that technology is dominated by men (Bray, 2007). Since technology is related to the knowledge that is associated with power (Green, 2002), domination by men is used as their tools to maintain their power over women (Toffoletti, 2007). 
However, Donna Haraway argues that women are not the "victim" of technology through the concept of cyborg in her Cyborg Manifesto. Her figure of cyborgs represents her idea of the relation between women and technology. She stated that:

There are several consequences to taking seriously the imagery of cyborgs as other than our enemies... The machine is not it to be animated, worshipped, and dominated. The machine is us, our processes, an aspect of our embodiment. We can be responsible for machines; they do not dominate or threaten us. We are responsible for boundaries; we are they (Haraway, 1991, p. 180).

For Haraway, cyborgs are reimagined and away from militarism and informatics domination (Bell, 2007). It refers to the idea that technology is not women's enemies and should not be either used to dominate or be dominated. Sofoulis stated that cyborgs figure is not about one dominant being, to be submissive and surrender to the machine, but rather about exploring the alliances and affinities between women and technology (Angerer, 1999). The goal is to gain gender equality. Thus, the figure of cyborgs represents the way of living with and against technology which stated by Haraway:

... It is an imagination of a feminist speaking in tongues to strike fear into the circuits of the super-savers of the new right. It means both building and destroying machines, identities, categories, relationships, space stories. Though both are bound in the spiral dance, I would rather be a cyborg than a goddess (Haraway, 1991, p. 181).

Haraway emphasizes her cyborgs' imagery as a powerful force to the denial of dualism but still powerfully feminist (Bell, 2007). This concept should not be misread as the rejection of feminism regardless of it rejects the goddess and radical feminism. She also declares that she had rather be a cyborg than a goddess which means that she had rather be a cyborg that creates herself along with her own rules than be a goddess that obeys the rules of male myth-making (Karremann, 2004). As she describes cyborg, the line between science fiction and social reality is connected. She emphasizes that the border between what is considered as science fiction or social reality is only an "optical illusion". Cyborgs enable a productive blurring of the binaries such as male/female, self/other, and culture/nature that have sustained Western cultural hierarchies (Schueller, 2005).

On the contrary, the depiction of a cyborg in some movies is frequently portrayed to be irrelevant to Haraway's concept of cyborg. Instead of blurring the notion of gender, cyborgs tend to appear as masculine or feminine in an exaggerated way (Holland, 2001). Such as the hyper-masculinity that depicted through Arnold Schwarzenegger's Terminator. He is also depicted to be more superior to others (Johnston, 2001). In contrast, Andreas Huyssen explains that female cyborgs are often portrayed as an object, exploitable, and the subject for men mastery through the Metropolis movie (Toffoletti, 2007). Thus, it emphasizes that female cyborgs are represented to be inferior to the male cyborg.

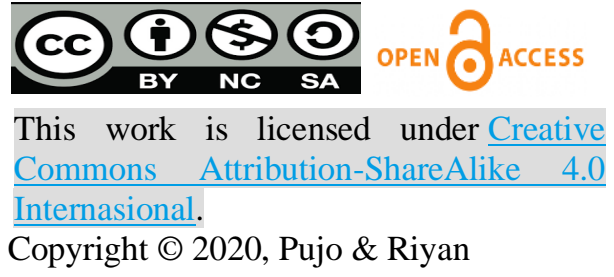

Copyright $\odot$ 2020, Pujo \& Riyan 
Another movie depicting cyborg which attracts the writers' attention, thus becomes the object of this study, is Ghost in the Shell (2017) movie. This movie was released in Indonesia on March 29, 2017, and directed by an English film director, Rupert Sanders (IMDb, 2017). Ghost in the Shell is an adaptation of Japanese manga with the same title which was written and illustrated by Masamune Shirow. This movie tells about the female cyborg that is created as a weapon named Major whose brain was taken from a girl named Mira Killian who is actually a Japanese antitechnology rebel named Motoko Kusanagi. The movie ends with Major finds her true identity.

The portrayal of Major as a female cyborg brings a hidden message through the shifting from the sexual object into the subject. The shifting itself can be achieved through the affiliation between women and technology regardless of the technology is considered as a tool to exploit women. It is able to break the stereotype that women do not have a place in the technological field.

By examining the narrative and non-narrative aspects of the movie, and utilizing Donna Haraway's critical concept of cyborgs in the analysis, the writers attempt to reveal how the female cyborg is represented in this movie. The writers argue that through the female cyborg's body, women can liberate themselves using the technology.

\section{LITERATURE REVIEW}

\subsection{Donna Haraway's Cyborg Manifesto}

A Cyborg Manifesto is an essay written by Donna Haraway in her book titled Simians, Cyborg and Women: The Reinvention of Nature. From her socialist point of view, she challenges the patriarchy by using the figure of cyborgs in order to support the feminism idea (Gane, 2006).

Haraway suggests the ideal non-binary, "post-gendered" paradigm, for which she sees the cyborg as a useful metaphor in order to address the issue of the binary system which is based on the concept of male and female as reinforcing a harmful state of existing patriarchy (Evans, 2016). She writes on her manifesto, "the cyborg is a kind of disassembled and reassembled, postmodern collective and personal self" (Haraway, 1991, p. 163) which symbolically refers to the "postgender world". The figure of cyborgs is able to eliminate the boundaries between human and animal, organism and machine, and physical and non-physical as well as the boundary between male and female. Nonetheless, Harraway's post-gendered cyborg image is not meant to negate or completely get beyond the concept of biological gender. Instead, it is meant to embrace the material reality of gendered bodies while simultaneously deconstructs "the totalizing identity of Woman" (Thweatt-Bates, 2012, p. 90).

\subsection{Women and Technology}

In her Cyborg Manifesto, Donna Haraway uses the image of cyborgs against the idealized, mythical goddess that is not only promoted by patriarchal but also radical feminism of the late 20th century (Karremann, 2004). She criticizes radical feminism which believes that technology

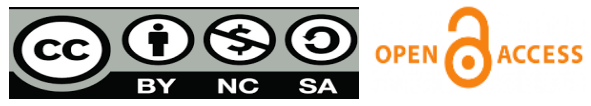

This work is licensed under Creative

Commons Attribution-ShareAlike 4.0

Internasional.

Copyright (C) 2020, Pujo \& Riyan 
is considered as patriarchal and incompatible with women. Technology is coded as patriarchal because it is dominated by men.

Haraway emphasizes her cyborgs' imagery as a powerful force to the denial of dualism but still powerfully feminist (Bell, 2007). Haraway's concept of cyborgs should not be misread as the rejection of feminism regardless it rejects the goddess and radical feminism. Additionally, at the end of her essay, she declares that she had rather be a cyborg than a goddess. Through this statement, she claims that she had rather be a cyborg that creates herself along with her own rules than be a goddess that obeys the rules of male myth-making (Karremann, 2004). That statement refers to the figure of a goddess that is worshipped for her femininity while cyborg is the figure of universality and neutral. It is not biased into one particular gender, race, or class.

\section{METHODOLOGY}

This research is conducted by using a qualitative method. The primary data of this research is a movie titled Ghost in the Shell (2017) which is directed by Rupert Sanders. As the secondary data to support the writers' arguments, the writers used offline and online sources such as books, ebooks, journal articles, and previous studies that are related to gender portrayal of a female cyborg, feminism, gender and technology, and Donna Haraway's Cyborg Manifesto.

This research focuses its analysis on the movie's main character named Major since she is portrayed as the only female leader figure in the movie. The depiction of Major's environment in New Port City is also discussed in order to construct the analysis of how Major is represented as a gendered cyborg. Analysis of the main character's environment is very imperative since it serves as her social space where she conceives, comprehends, and justifies her social and biological identity. Then, the writers limit the study only to the portrayal of Major's gender identity in order to reveal the relation of women and technology within the movie.

In doing the study, the writers examine the primary data based on narrative and non-narrative aspects as in Corrigan and White (2012). Centered on those two aspects, the authors choose several scenes in the movie related to the issue to be analyzed. In narrative aspects, the writers analyze the plot and the story as well as the characters in the movie. For the non-narrative aspects, the writers analyze the cinematography and mise-en-scène.

\section{RESULTS AND DISCUSSION}

\subsection{New Port City as Patriarchal Society}

Major lives in a city called New Port City. This city has the tendency of being a patriarchal society. According to Barker (2004), patriarchy is the social order in which social institutions and social

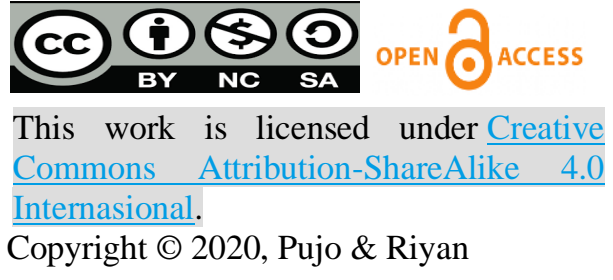

Copyright ( 2020 , Pujo \& Riyan 
practices are dominated by men over subordinated women. In other words, men have more power than women in society.

The first factor that marked Major is surrounded in patriarchy is seen from the structure of the institution. The high-ranking officials in this movie are dominated by men. The role of Hanka Robotics' CEO is played by a man named Cutter. Then, Section 9's Chief is a guy named Aramaki. The President of the African Federation is also played by a man. Other than that, Dr. Osmond has a role as Hanka's delegation. Positioning men as leaders refer to the concept of patriarchy which is male-headed family, 'mastery', and superiority (Barker, 2004). The fact that this movie follows that concept, New Port City can be called the patriarchal society.
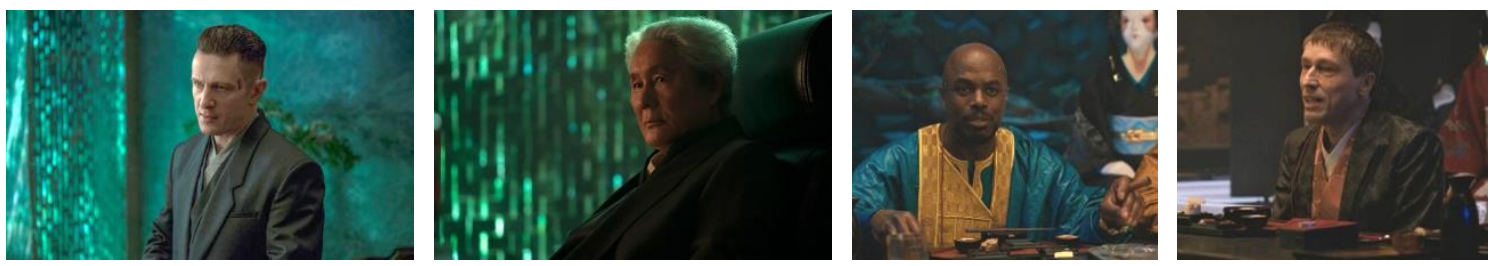

Figure 1. Men as the high-rank officials

Moreover, men are not only portrayed as the dominant one in the high-ranking position, but they are also portrayed to be the army.
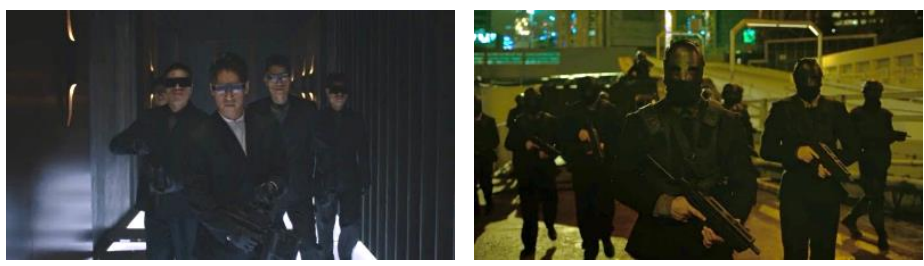

Figure 2. Men dominate the army

Those pictures are the armies presented in this movie. The first picture is the terrorists that attack the President of the African Federation, and the second picture is Hanka's security team. Both of those armies are dominated by men.

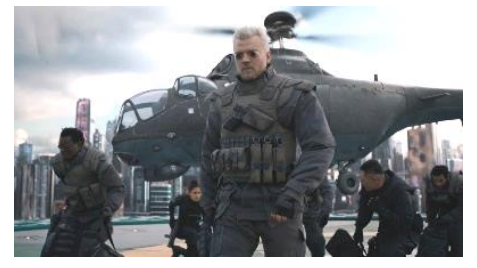

Figure 3. Public Security Section 9

From figure 3, the Public Security of Section 9 is dominated by men. It is seen in the picture that Batou is placed at the front of the army while Ladriya as the female soldier is placed at the very back of the formation. This arrangement of the characters is used to direct attention to a specific 30

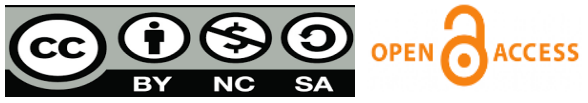

This work is licensed under Creative Commons Attribution-ShareAlike 4.0 Internasional.

Copyright (C) 2020, Pujo \& Riyan 
area (Mamer, 2009) which on that scene is Batou, the male soldier. Thus, the attention is directed into Batou who portrays that men become the center of attention. Furthermore, the men's domination and the formation of those armies represent that women are not strong enough to work as soldiers. The patriarchy assumes that women are physically weak and dependent (Gavin \& Porter, 2015). In other words, women are considered as not capable of doing a job that requires strength. Thus, this is the other factor that marked this society as a patriarchal society.

The appearance of robotic geisha and the advertisements in the city depict how New Port City is the portrayal of patriarchal society.
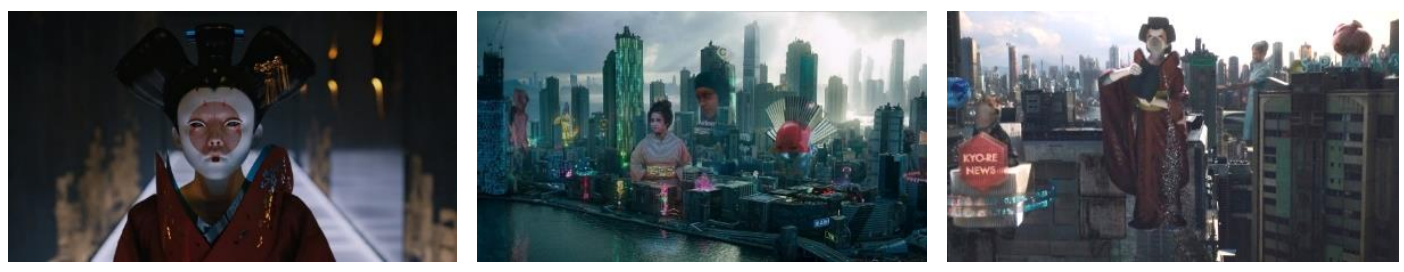

Figure 4. The robotic geisha and the advertisements in town

The first picture is the figure of robotic geisha made by Hanka. The second and third pictures are the holographic advertisements that appear in the city. The women figure on those holographic advertisements is shown in a very large size which has the attention to draw (Pongratz, 2003). Therefore, the women on those holographic advertisements are functioned to emphasize that they are the object of the advertisements. All of them represent how women are portrayed as the object rather than the subject created by men and advertised by them. It depicts the status of women as men's property in a patriarchal society (Gavin \& Porter, 2015).

Other than that, the second and third pictures in figure 4 show New Port City as the setting of the movie. The extreme long-shot is used in order to capture the city around Major. Through this shot, the surrounding primarily fills the screen (Mamer, 2009). It captures the futuristic cityscape which represents this city. The holographic figures are shown in large size and more than one to emphasize that the technology has dominated the city. The third picture is also dominated by grey color which is associated with technology and machinery (Fehrman \& Fehrman, 2004). Furthermore, the use of technology is considered to be patriarchal (Toffoletti, 2007) which means the domination of men. Toffoletti (2007) mentioned that technology is used by men to maintain their power over women who have a position as passive victims under patriarchal control. They exclude women from technology and considered as separating them from their true form which is nature and body. As a result, the technology means to be patriarchal. Thus, it gives more emphasis that the society in Ghost in the Shell is a patriarchal society.

The explanations above portray the society where Major lives. Through the domination of men and the placement of women as subordinate, New Port City has a tendency as a patriarchal society. Thus, it affects how Major is portrayed in this movie. 


\subsection{Major's Existence as Female Cyborg}

Ghost in the Shell is started with an explanation about Hanka Robotics, a company that is funded by the government, which conducts an experiment for military operations. They transplant a human brain into a fully synthetic body. Therefore, they combine the strongest quality of humans and robots. In the next scene, the process of creating Major is shown.
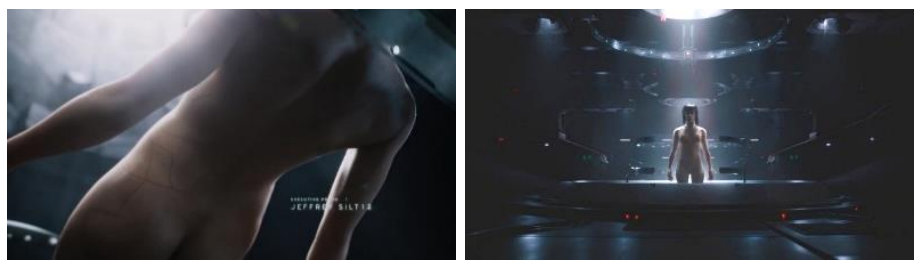

Figure 5. Major is shown naked with medium long-shot and slow camera movement.

The usage of slow camera movement and a medium long-shot bring a hidden meaning to these scenes. While the slow camera movement makes the audiences are able to see the detail of Major's body, the medium long-shot makes her knees-up parts of her body are exposed (Villarejo, 2007) which are her breast and buttocks. Instead of designing her body as a robot, her body is shaped to be curvy such as an ideal women's body. Therefore, her body is clearly marked as female. In addition, the camera "takes pleasure" in visualizing Major's nudity. The camera movement represents the male's gaze as if enjoying a woman's naked body (Silvio, 1999). In addition, Major is highlighted in the second picture. The lab around her is shown to be darker in order to highlight her body. The highlight is used to emphasize a certain character or object (Corrigan \& White, 2012) which emphasizes Major's body. Therefore, the audiences are able to look at her body clearly as a female cyborg who has a curvy body, big breasts, and buttock which represent women as the sexualized object.

Furthermore, the exposure of the Major's body is depicted in another scene. Her ability to become invisible requires her to use a costume.
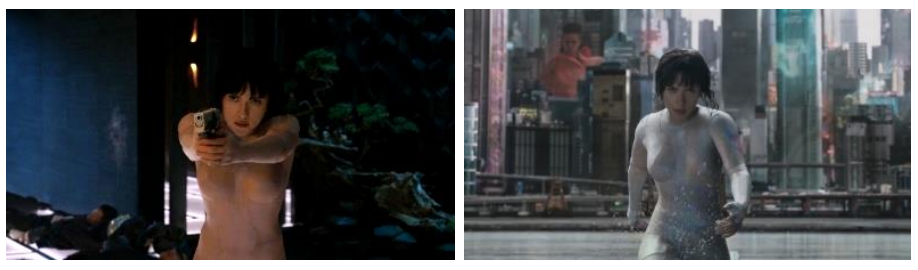

Figure 6. Major using her invisible suit for some missions.

Those two pictures above show Major in her costume which has the same color as her skin and in a really tight design which makes her look like she wears nothing. As a result, Major's body shape is exhibited by the costume. While, the male cyborgs', Batou and Kuze, body are never shown

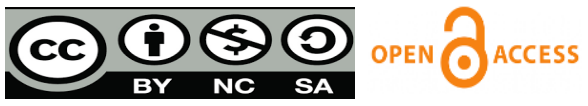

This work is licensed under Creative Commons Attribution-ShareAlike 4.0 Internasional.

Copyright (C) 2020, Pujo \& Riyan 
naked. Even their bodies are never being highlighted and the camera movement does not treat them as it treats Major. Those differences depict women as the sexualized object for the male gaze enjoyment (Silvio, 1999).

The portrayal of Major as a sexual object also appears when Major does the mission.
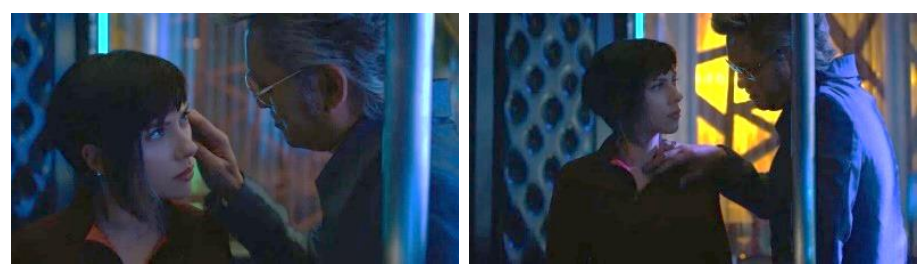

Figure 7. Major is touched by a guy at the yakuza club.

This scene is when Major tries to trace Kuze in a nightclub. When she is inside, Major is stopped by two securities and brings her into a room. Then, Major's hands are handcuffed on a pole and a guy touches her hair and body and forces her to dance. This scene emphasizes Major's body as their desire fulfillment. Her curvy body is designed as the result of men's domination in technology. As stated by Laura Mulvey (1975, p. 11), "in a world ordered by sexual imbalance, pleasure in looking has been split between active/male and passive/female." In other words, women are placed as passive objects to be looked at and displayed while men are the active subjects who look. She mentioned that women in narrative cinema have one role as a passive erotic object for the male gaze of male spectators. On the other side, men are able to project their fantasy on her or the agent of the look, with whom spectators identify to get pleasure from vicarious control and possession of the women (Chaudhuri, 2006). Thus, the way major is portrayed through the camera movement and wearing that costume is purposed to fulfill the male gaze, portraying her as the sexual object.

Not only her portrayal as the sexual object, but Major is also portrayed as the subject. She has the power to make a decision for herself. It is seen when Major denies the objectification that she receives from two men at the yakuza club.

\section{$31: 17$}

The yellow glasses guy : ...if you do not want to talk, maybe you want to dance!

The bald guy

Major
: (Electrocuted Major).

: No! Enough! The truth is, I was not built to dance.

The dialogue above is from the scene where Major is in a room of the nightclub and forced to tell the guys what she actually does at that nightclub. Since Major does not want to tell them, she is electrocuted and forced to dance to fulfill their desire. However, Major said that she is not built to

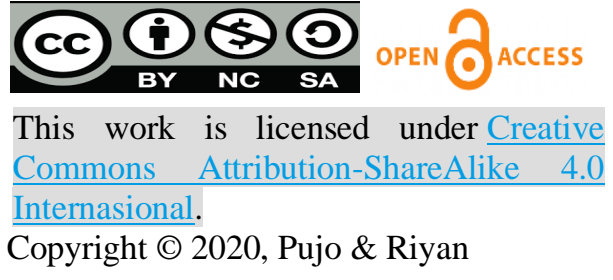


be their entertainer because she is built to fight the terrorists. Then, she fights those two guys and goes to Kuze's hiding place. It emphasizes the idea that Major is able to reject the sexual objectification through the technology that is enhanced on her body. Even though her mechanic body is hyper-sexualized and makes her being objectified, she can avoid something that she does not want to do by the technological enhancement itself.

There is also a time where Aramaki asks Major to suggest what he should do to Cutter.

$$
1: 34: 29
$$

Aramaki : Major. I'm with Cutter. Is there anything you'd like to say to him?

Major : Tell him this is justice. It's what I was built for.

Aramaki : So....do I have your consent?

Major : My name is Major, and I give my consent.

This dialogue is from the scene after Major fights the spider tank. She is asked by Aramaki does he has her consent to kill him. Then, Major says he has her consent, and it is for justice. After that, Aramaki kills Cutter. What Major does in this scene portrayed her power towards Aramaki. Considering that Aramaki is Major's chief, he is able to do what he wants without asking Major. However, he wants Major's permission to kill Cutter. It depicts how Major also has the authority towards Aramaki. This scene represents the rejection of the stereotype that women do not have a voice in a patriarchal society. They do not have the same right to speak their opinion on decision making (Barlow, 2009). On the other side, this movie shows that Major has a right to be involved in making a decision.

Major is also portrayed to be powerful because of the technological enhancement that she got. She is frequently portrayed that her own body is pushed past its limits such as jump off the buildings, being electrocuted, and ripped her arms off.
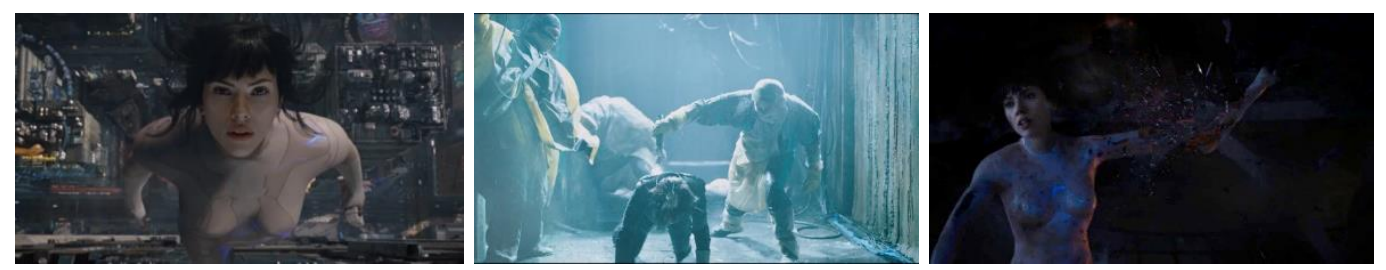

Figure 8. Major when she jumps off the building, being electrocuted, and ripped off her arms

The first scene is when she jumps off the building when she carries a mission. The second scene is when she gets electrocuted by Kuze's allies. The last picture is when Major destroys the tank to

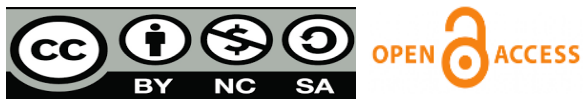

This work is licensed under $\underline{\text { Creative }}$ Commons Attribution-ShareAlike 4.0 Internasional.

Copyright (C) 2020, Pujo \& Riyan 
save Kuze. Those scenes portray how Major's cyborg body makes her able to pass her limits and endure the pain. While those acts have never been done by Batou or Kuze who are also cyborgs. Through those scenes, Major is portrayed to be very determined with her goal. Despite all the dangers that may come to her, she acts without hesitation. The traditional gender roles labeled men to be fearless, goal-oriented, and have more authority or more dominant (Lueptow, 2013). Thus, the enhancement that Major got is able to break the gender stereotype.

\subsection{Women and Technology}

In her book titled Cyborgs and Barbie Dolls: Feminism, Popular Culture, and the Posthuman Body, Kim Toffoletti (2007, pp. 21-23) recounts several authors' views toward the relation of women and technology. According to Judy Wajcman, in the traditional context, the concept of technology is weighted against women, and its definition has a male bias. In other words, technology is considered to be patriarchal and incompatible with women. Leina Green sees that technology has a relation to power and privilege. She mentions that knowledge is associated with power. It is seen through the development of technology that the one who develops the technology may enjoy the advantages and benefits. Thus, technology is dominated by men in order to dominate society, while at the same time, as Cynthia Cockburn points out, to maintain power over women, men use technological tools. Moreover, Andreas Huyssen argues that women are othered from the technology. They are considered as exploitable, an object, being controlled, and compatible for men's mastery.

In line with the views above, the portrayal of Major existence as a female cyborg in this movie represents those relations of women and technology. As has been explained in the previous subchapter, Major is portrayed as the object. Her cyborg body is exploited by Hanka as a weapon. She is also being sexualized through the camera gaze that in some way highlights her breast and buttocks. There are also some scenes that show Major is forced to dance by two men to fulfill their desire. Moreover, she also takes orders from Aramaki as her chief. She is also produced by a corporation that is dominated by men. These facts make her the object of man mastery.

Another thing, as depicted in the movie, Major is created by Hanka which plans to produce another Major-like cyborg. It means that Hanka treats Major as their product, a commodity to be purchased and consumed. Therefore, in terms of technology, Major's existence as a cyborg is used for personal interests. While, on the other hand yet simultaneously, her image as a female cyborg seems to rearticulate the unequal position of women and men in society, with the emphasis on the subordinate position of women.

The portrayal of Major as a female cyborg brings an image that women cannot stand as herself. Before her brain is transplanted into the artificial body, she is portrayed as a woman named Motoko Kusanagi. Motoko is a Japanese antitechnology rebel. When she was spending the days with the

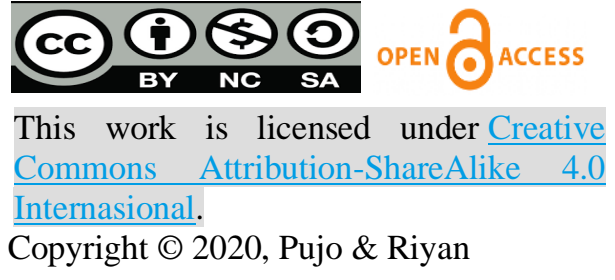

Copyright ( 2020 , Pujo \& Riyan 
other rebels who were also runaways, she was captured by Hanka Robotics and could not save herself. She was dragged and helpless. She even cried to Hideo to save her for she did not have sufficient martial ability to defend herself. Conversely, when she had turned into Major, she became good at martial arts for she had undergone technological enhancement using cybernetic parts. Not only able to defend herself, but she was also becoming a very effective killer and the finest justice upholder.

The role of the technology is to enhance Major's ability, making her competent in performing her job. It also makes her able to achieve her rank as major. This technological intervention emphasizes the problem that women cannot reach their success by themselves. In a particular sense, it represents the notion that women cannot be independent. They need help from others or using tools to become successful. It signifies the fact that she will never have her strength and her fighting ability without that body made from high cybernetic technology. The enhancement makes her more powerful than her in the previous organic body.

At the beginning of the movie, Major is portrayed as an object. She is considered as a weapon, and she takes orders from Aramaki. As the story progresses, she gets her consciousness back. Then, her consent is needed by Aramaki. Major who was initially considered as an object is turned into a subject. In this context, the shift of her role in this movie represents that women are no longer the victim of technology.

Bernadette Flynn (1994) stated in her essay that the technology is used by women in order to reject the patriarchal forms. The traditional gender role that casts women as weak is rejected through the figure of a female cyborg. The concept of cyborg itself is used by Haraway to emphasize that women are able to liberate themselves through the technology that cast them as the subordinate one. It is a hope for women liberation since cyborg is not gender-biased. Furthermore, technology is the means for women to enhance their ability and overcome oppression.

In the mainstream perspective, as pointed out by Francesca Bray (2007), men are naturally having an affinity with technology and actively engage with a machine. On the contrary, women are viewed as having fear of or dislike technology. They may use the machine, but they are considered to be a passive beneficiary. That being said, they only use the machine but do not make or tinkering with it. This means that in this sense women are not considered in particular as the subject of the technology. Moreover, in a patriarchal society, technology is coded as masculine due to its complexity and the relation with knowledge. That complexity then associated with a stereotype that sees men as rational while women are seen as irrational. Thus, the assumption of women that is less capable in technology emerges which resulting in the domination of men on the technology. As Silvio (1999) points out, the domination of men in technology affirms the idea of mind as masculine.

However, Donna Haraway suggests that "cyborg writing is about the power to survive, not on the basis of original innocence, but on the basis of seizing the tools to mark the world that marked 36

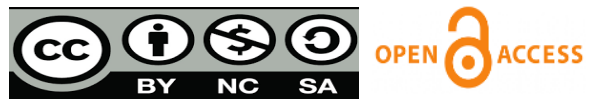

This work is licensed under Creative Commons Attribution-ShareAlike 4.0 Internasional.

Copyright (C) 2020, Pujo \& Riyan 
them as other" (Haraway, 1991, p. 175). In other words, she places a cyborg as a figure that portrays the relationship between women and technology. The technology that is coded as patriarchy makes women seen as Other. Nevertheless, women can use it as a tool to liberate themselves. Haraway also says, "the machine is not it to be animated, worshipped, and dominated" (Haraway, 1991, p. 180) which refers to the idea that it is not a tool to dominate or being dominated by either men or women. The kind of women empowerment that is portrayed from the figure of a cyborg is being liberated by technology that actually oppresses women and survives the oppression. In other words, the concept of cyborg is a matter of gaining the gender equality, not a matter of who can be more powerful than others.

The analysis of the relation between women and technology at the above presents the idea of the ambivalence between technoculture and gender in society. Behind the oppression that women received from the domination of men in technology, they are able to obtain the skill and being valued through their affiliation with technology. It is the result of the shifting idea of gender bias in technology in society nowadays. Even though the technology is still dominated by men, some women begin to have an interest in technology due to the increase of gender equality awareness in society. The stereotype of women as incompatible in technology is slowly decreased by some women that choose to learn technology and pursue a career in this field. Thus, the concept of patriarchy which placed men as the ones who control the technology has been shifted by the existence of women who pursue a career in technology. Moreover, the concept of patriarchy in which men dominate the technology is not compatible with the current condition where women also have a chance to be skilled and valued in technology.

\section{CONCLUSION}

Women have been considered to be the "victim" of technology. Its existence is used by men as a tool to maintain their power over women. Othering women from technology means considering them as sexual objects, exploitable, being controlled, and compatible with men's mastery. Opposing this, Donna Haraway argued in her Cyborg Manifesto that women are not the "victim" of technology through her concept of cyborg. The affiliation between women and technology is beneficial for women.

The portrayal of New Port City as a patriarchal society affects the depiction of Major's existence as a female cyborg. Throughout this movie, Major's existence is shifted from a sexual object, weapon, and compatible for men mastery, into the subject who is capable to choose her own life path. This portrayal shows the relationship between women and technology. The technology which is developed by men's interest is able to make women overcoming the oppression and enhance their ability. It changes them from being helpless into empowered. Therefore, the affiliation between women and technology is portrayed in the figure of Major as a female cyborg which is considered as women empowerment.

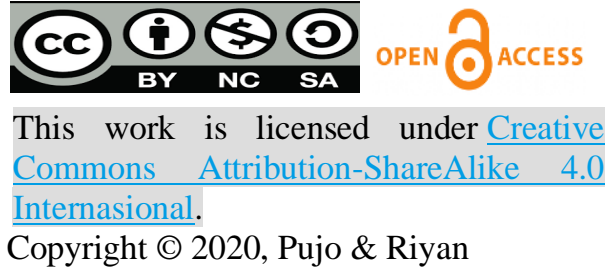

Copyright ( 2020 , Pujo \& Riyan 
WOMAN AND TECHNOLOGY: A STUDY ON GENDER PORTRAYAL OF A FEMALE CYBORG IN GHOST IN THE SHELL (2017) MOVIE

Lire Journal (Journal of Linguistics and Literature) P-ISSN: 2598-1803 E-ISSN: 2581-2130 Volume 4 Number 1 March 2020

To conclude, Ghost in the Shell movie promotes the paradox of the relationship between women and technology through a female cyborg character named Major. It empowers women to gain their freedom, even from something that actually oppresses them. It is a new opportunity for women to become skilled, important, and valued by affiliating with technology while it also portrays the acceptance of men's domination in society.

The writers expect that this research is able to give a contribution to feminism and technoculture studies. In addition, future research could explore more about the relation of race and technology regarding that cyborgs are frequently presented to have a white body in other movies. This issue is still regarded as a big challenge in Hollywood in order to promote the awareness of the equality of women in all races and appreciate the existence of women of color.

\section{ABOUT THE AUTHORS}

1. Pujo Sakti Nur Cahyo is a lecturer of English Department Universitas Airlangga.

2. Riyan Evrilia Suryaningtyas is a student of English Department Universitas Airlangga.

\section{REFERENCES}

Angerer, M.-L. (1999). Space Does Matter: On Cyber and Other Bodies. European Journal of Cultural Studies, 2(2), 209-229. doi:10.1177/136754949900200204

Barker, C. (2004). The SAGE Dictionary of Cultural Studies. London: SAGE Publications.

Barlow, R. (2009). Women and Conflict. In R. Bechler (Ed.), 50.50: Women Writers, Politics and Voice (Vol. 5, pp. 16-19). London: openDemocracy.

BBC. (2017). How it Feels to Meet Sophia, a Machine With a Human Face. BBC Future. Retrieved from https://www.bbc.com/future/article/20170906-how-it-feels-to-meetsophia-a-machine-with-a-human-face

Bell, D. (2007). Cyberculture Theorists: Manuel Castells and Donna Haraway. New York: Routledge.

Bray, F. (2007). Gender and Technology. Annual Review of Anthropology, 36(1), 37-53.

Chaudhuri, S. (2006). Feminist Film Theorists: Laura Mulvey, Kaja Silverman, Teresa de Lauretis, Barbara Creed. Abingdon: Routledge.

Cooper, S. (2010). Questions Concerning Technoculture. Science as Culture, 19(2), 255-258. doi:10.1080/09505430903214435

Corrigan, T., \& White, P. (2012). The Film Experience: The Introduction. Boston: Bedford/St.Martins.

Evans, C. L. (2016). Women of the Future: Gender, Technology, and Cyborgs in Frank Herbert's Dune. (Master), Université Laval, Quebec.

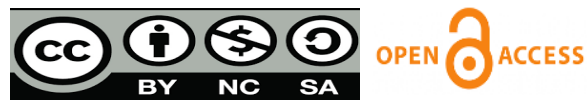

This work is licensed under Creative Commons Attribution-ShareAlike 4.0 Internasional.

Copyright @ 2020, Pujo \& Riyan 
WOMAN AND TECHNOLOGY: A STUDY ON GENDER PORTRAYAL OF A FEMALE CYBORG IN GHOST IN THE SHELL (2017) MOVIE

Lire Journal (Journal of Linguistics and Literature) P-ISSN: 2598-1803 E-ISSN: 2581-2130 Volume 4 Number 1 March 2020

Fehrman, K. R., \& Fehrman, C. (2004). Color: The Secret Influence (Second ed.). Upper Saddle River: Pearson Education.

Flynn, B. (1994). Woman/Machine Relationships: Investigating the Body within Cyberculture. Media Information Australia, 72(1), 11-19. doi:10.1177/1329878X9407200104

Gane, N. (2006). When We Have Never Been Human, What Is to Be Done?: Interview with Donna Haraway. Theory, Culture \& Society, 23(7-8), 135-158. doi:10.1177/0263276406069228

Gavin, H., \& Porter, T. (2015). Female Aggression. Hoboken: Wiley Blackwell.

Green, L. (2002). Technoculture: From Alphabet to Cybersex. New South Wales: Allen \& Unwin.

Haraway, D. J. (1991). Simians, Cyborg and Women: The Reinvention of Nature. New York: Routledge.

Holland, S. (2001). Descartes Goes to Hollywood: Mind, Body, and Gender in Contemporary Cyborg Cinema. In J. R. Johnston (Ed.), The American Body in Context: An Anthology (pp. 11-30).

IMDb. (2017). Ghost in the Shell (2017). Internet Movie Database. Retrieved from https://www.imdb.com/title/tt1219827/?ref_=ttrel_rel_tt

Johnston, J. R. (2001). Cybernetic Bodies. In J. R. Johnston (Ed.), The American Body in Context: An Anthology (pp. 73-77). Delaware: Scholarly Resource.

Karremann, I. (2004). 'I'd Rather Be a Cyborg than a Goddess': Reading the Cyborg Poetics of Eavan Boland. Nordic Irish Studies, 3, 113-126.

Love, T. (2018). Robots Have a Diversity Problem. OneZero. Retrieved from https://medium.com/s/thenewnew/robots-the-new-identity-politics4b36700630db?mbid=social_fb

Lueptow, L. B. (2013). Sex Stereotypes: An Underlying Dimensions. In S. Carreon, A. C. K. Borman, \& P. J. Dubeck (Eds.), Women and Work: A Handbook. New York: Routledge.

Mamer, B. (2009). Film Production Technique: Creating the Accomplished Image. South Melbourne: Wadsworth Cengage Learning.

Mulvey, L. (1975). Visual Pleasure and Narrative Cinema. Screen, 16(3), 6-18. doi:10.1093/screen/16.3.6

Pongratz, G. (2003). Female Stereotypes as Reflected in English Advertising. (Master), University of Graz, Graz.

Schueller, M. J. (2005). Analogy and (White) Feminist Theory: Thinking Race and the Color of the Cyborg Body. Signs, 31(1), 63-92. doi:10.1086/431372

Silvio, C. (1999). Refiguring the Radical Cyborg in Mamoru Oshii's "Ghost in the Shell". Science Fiction Studies, 26(1), 54-72.

Thweatt-Bates, J. (2012). Cyborg Selves: A Theological Anthropology of the Posthuman. Surrey: Ashgate Publishing Ltd.

Toffoletti, K. (2007). Cyborgs and Barbie Dolls: Feminism, Popular Culture and the Posthuman Body. New York: I.B. Tauris.

Villarejo, A. (2007). Film Studies: The Basics. New York: Routledge. 